\title{
The Impact of International Economic Sanctions on Industrial Output of the Russian Federation
}

\author{
Yulia KOSENKOVA
}

Financial University under the Government of the Russian Federation, Moscow, Russia; kosenkova@list.ru

\begin{abstract}
Since 2014, a number of foreign countries and interstate associations have been imposing financial and economic sanctions on the Russian Federation. The official goal of the sanctions was to force Russia to change its foreign policy. The sanctions were aimed at key economic sectors: energy, defense, mechanical engineering, financial sector. Imposed sanctions were to cause economic slowdown in Russia and worsen several macroeconomic performance indicators, such as inflation, employment, foreign trade balance, net capital inflow, industrial output etc. The article seeks to analyze the impact of sanctions on Russian industry, therefore it contains the definition and classification of sanctions imposed on Russia, characterizes Russian pre-sanctions industrial production, and evaluates the state of industry after the sanctions were introduced. The conclusion on the effectiveness of sanctions will be made based on comparison of indicators of Russian industrial output in pre- and post-sanctions period.
\end{abstract}

Keywords: international financial and economic sanctions; Russian industry; impact of sanctions; mining; manufacturing; industrial production index; import substitution

JEL Classification: F51, F42, F23

\section{Introduction}

The main trend of global economy today is a transition from liberalism, globalization and free trade to neomercantilism и protectionism (Orekhovsky 2018). The USA, where financial and economic sanctions have been actively implied during the last 5 years to solve economic and political problems with Russia, China, Mexico etc. can be a good example.

The problem that sovereign states influence economic and political decision-making by economic coercion is not new in worldwide practice. According to G.C.Hufbauer (Hufbauer 2007), in 1995-2000 there were 47 cases of imposing economic sanctions, mostly initiated by the USA and the UK (Hufbauer 2007). In 2000-2006, G.C.Hufbauer mentions 13 cases (Hufbauer 2007), initiated mainly by the USA and the EU. A.Baldwin, D.Cortright, M.Doxey, R.J.Ellings, K.A.Elliott, J.Dashti-Gibson, L.Davis, D.Lektzian and other authors have also studied effectiveness of international economic sanctions.

In this article sanctions will be defined as economic and financial restrictive measures imposed by one party of international economic relations (state, group of states, international organization) on another party (state, group of states) in order to force the latter to change its political direction or economic policy.

G.C.Hufbauer in his work "Economic Sanctions Reconsidered" has defined sanctions as "deliberate, government-inspired withdrawal, or threat of withdrawal, of customary trade or financial relations" (Hufbauer 2007) for political purposes. This definition reflects interconnectedness of political and economic causes of sanctions as well as correlation between political and economic leverages over the target state.

Application of international economic sanctions against Russia has raised interest in this issue among Russian researchers - Nureev R.M., Busygin E.G., Zagashvili V., Bulatova A.I., Petrakov P.K., Novikov, S.V., Lastochkina, V.V., Solodova, A.D. etc.

The purpose of this study is to evaluate the impact of sanctions on Russian industrial output. In order to achieve the purpose, the following tasks were solved:

- to analyze and classify sanctions imposed on Russia on various grounds;

- to characterize Russian industry before sanctions were imposed; 
- to evaluate the change of key industrial indicators as a result of sanctions.

Achieving this goal will allow to judge the effectiveness and expediency of applying those measures. There is no doubt that the cost of such influence is extremely high both for initiating and target countries. The question is whether the goals set by the initiating country are being achieved by imposing sanctions.

\section{Methodology}

In order to achieve the purpose of this study, international economic sanctions have been analyzed and classified by range of criteria, such as countries which imposed sanctions, sectors sanctions were aimed at, territorial coverage, and their influence on Russian economy. Russian industry in pre- and post-sanctions period has been characterized based on statistical data. The data in this study were provided by the Federal Service for State Statistics of the Russian Federation (Rosstat), therefore objectivity of the results directly depends on the objectivity of the data of the Federal Service for State Statistics. The indicators used to characterize Russian industry were industrial production in value terms, industrial production index, balanced financial result, cost per 1 ruble of manufactured products. Evaluation indicators allowed to estimate the change in the industrial production volume in value and physical terms, profit and loss of output in branches of industry, and unit cost for production. Besides the Rosstat data, statistical information provided by the Bank of Russia has been used. The study required the use of statistical method, comparison and index methods, horizontal analysis, and methods of analysis and synthesis.

\section{Results}

Financial and economic sanctions can be classified on various grounds. In particular, Nureev R.M. in his monograph " Economic sanctions against Russia and Russian anti-sanctions: goals and results" divides sanctions based on the aims of initiating country into:

- Sanctions connected with change of political regime and democratization;

- Sanctions connected with disruption of military adventures;

- Sanctions connected with military impairment;

- Sanctions connected with significant political changes (Hufbauer 2007).

International financial and economic sanctions imposed on Russia might fall into the first category. The reason for it was the reunification of Russia and Crimea as well as civil unrest in Ukraine. At the same time, it is necessary to note that economic contradictions between Russia and the USA, competition in fuel and energy sectors in particular, are also the basis for sanctions imposition.

The first anti-Russian sanctions package was enforced in mid-March 2014. Later it has been broadened with new actors, some of which imposed their own sanctions and some have joined the existing ones. In order to provide a precise evaluation of the impact of sanctions on the industrial output in Russia, it is necessary to analyze the economic essence of sanctions and classify them according to different characteristics. The analysis and classification of financial and economic sanctions allow to group them in accordance with the following criteria (Table 1). 
Table 1. Classification of international financial and economic sanctions

\begin{tabular}{|c|c|}
\hline Classification categories & Types of sanctions \\
\hline Actors imposing sanctions & $\begin{array}{l}\text { Sanctions imposed by: } \\
\text { - } \text { OECD } \\
\text { - } \quad \text { The European Parliament } \\
\text { - } \quad \text { The European Free Trade Association } \\
\text { - } \quad \text { The European Bank for Reconstruction and Development } \\
\text { - } \quad \text { The World Bank } \\
\text { - } \quad \text { countries (USA, UK, Canada, Australia etc.) }\end{array}$ \\
\hline Branch & $\begin{array}{l}\text { Sanctions aimed at: } \\
\text { - } \text { financial sector } \\
\text { - } \text { fuel and energy sector (oil and gas extraction, in particular) } \\
\text { - defense industry } \\
\text { - } \text { machinebuilding and shipbuilding } \\
\text { - } \text { space industry, electronics, IT-business } \\
\text { - } \text { foreign trade } \\
\text { - } \text { energy } \\
\text { rail transport }\end{array}$ \\
\hline Geography & $\begin{array}{l}\text { Sanctions aimed at: } \\
\text { - } \quad \text { Crimea and Sevastopol } \\
\text { - } \quad \text { Russian Federation in general } \\
\text { - The Eurasian Economic Community }\end{array}$ \\
\hline Effect on Russian economy & $\begin{array}{l}\text { - depriving Russian economic actors of access to foreign } \\
\text { credit resources; } \\
\text { ban on high-tech products supply to Russia (including } \\
\text { technology and equipment for oil production, space } \\
\text { industry, defense enterprises), as well as so called dual-use } \\
\text { products; } \\
\text { - complication of foreign trade operations, outright ban on } \\
\text { the purchase of Russian goods in accordance with the } \\
\text { approved list; } \\
\text { ban on investment in infrastructure, transport, } \\
\text { telecommunications and energy sectors, oil, gas and } \\
\text { minerals extraction }\end{array}$ \\
\hline
\end{tabular}

Thus, the Russian Federation is subject to a range of various sanctions. They are aimed at influencing a variety of sectors of the economy through direct restrictive and prohibitive measures. The ultimate goal of all these diverse sanctions is inability to overcome technical and technological backwardness, banning the arrival of new technologies, weakening Russia's position in international markets, reducing opportunities for credit financing, and as a result - slowing economic growth, stagnation in priority sectors of the Russian economy.

The analysis shows that sanctions can influence Russian industrial production, both directly and indirectly. Direct impact applies to:

- ban on the supply of modern equipment and technology for oil extraction, defense, space industry, dual-use products and technologies to Russia;

- $\quad$ challenging access to foreign markets (cancellation of duty-free import of a number of goods to the US, increase of import customs duties for a number of countries), outright ban on the purchase of more than 250 Russian goods; 
- non-involvement in joint investment projects in Russia (projects of the World Bank, the Overseas Private Investment Corporation, the European Investment Bank, investment projects of private companies etc.)

Indirect impact results in banning of Russian business entities from international financial markets, foreign credit resources, debt financing opportunities. The ban on debt financing applies to a wide range of economic entities in various industries: banks (Sberbank, VTB, Rosselkhosbank, Vneshekonombank, Gazprombank etc.), defense enterprises (Uralvagonzavod, Oboronprom, United Aircraft Corporation etc), fuel and energy complex enterprises (Rosneft, Transneft, Gazpromneft, Lukoil etc), industrial enterprises (OOO "Russkiye Mashiny", Rusal, OOO "Nasosy Ampika", United Shipbuilding Corporation, Mytishchi machine-building plant, Izhevsk Mechanical Plant, Izhmash group, Mayak machine-building plant, OOO Foreign Economic Association "Technopromexport", OJSC "Siloviye Mashiny - ZTL, LMZ, Elektrosila, Energomashexport" etc)

A rise in the inflation rate can be considered consequential impact of sanctions on the Russian economy. According to Rosstat data, consumer price index, one of the main inflation indicators, was $6.57 \%$ in 2012 and $6.47 \%$ in 2013. In 2014 and 2015 it increased to $11.35 \%$ and $12.91 \%$ respectively, causing twofold increase in inflation. Since 2016 Russian economy has adapted to restrictions, therefore inflation rate fell (Figure 1).

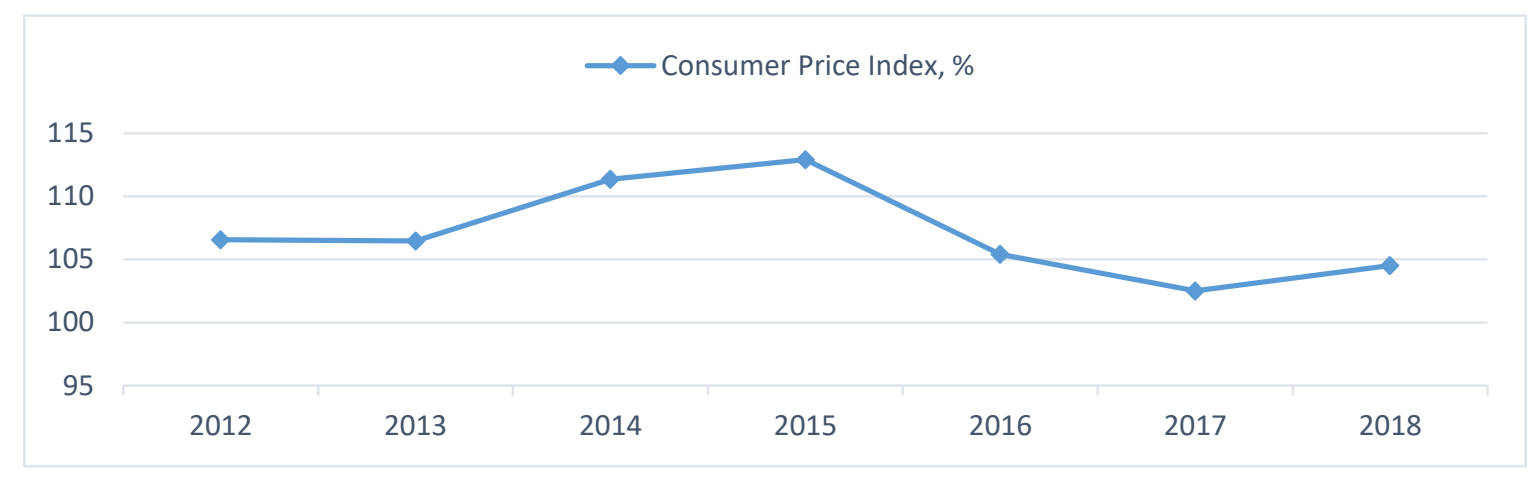

Figure 1. Consumer price index in 2012-2018 (according to the Federal Service for State Statistics data).

Despite the opinion expressed in chapter 2.4 of "Economic Sanctions against Russia: Expectations and Reality", devaluation of the Russian ruble in 2014-2019 can be considered a positive consequential impact (Nureey and Petrakov 2016). Figure 2 shows the US dollar and Euro against the Russian ruble at the beginning of the year (according to data of the Central Bank of the Russian Federation).

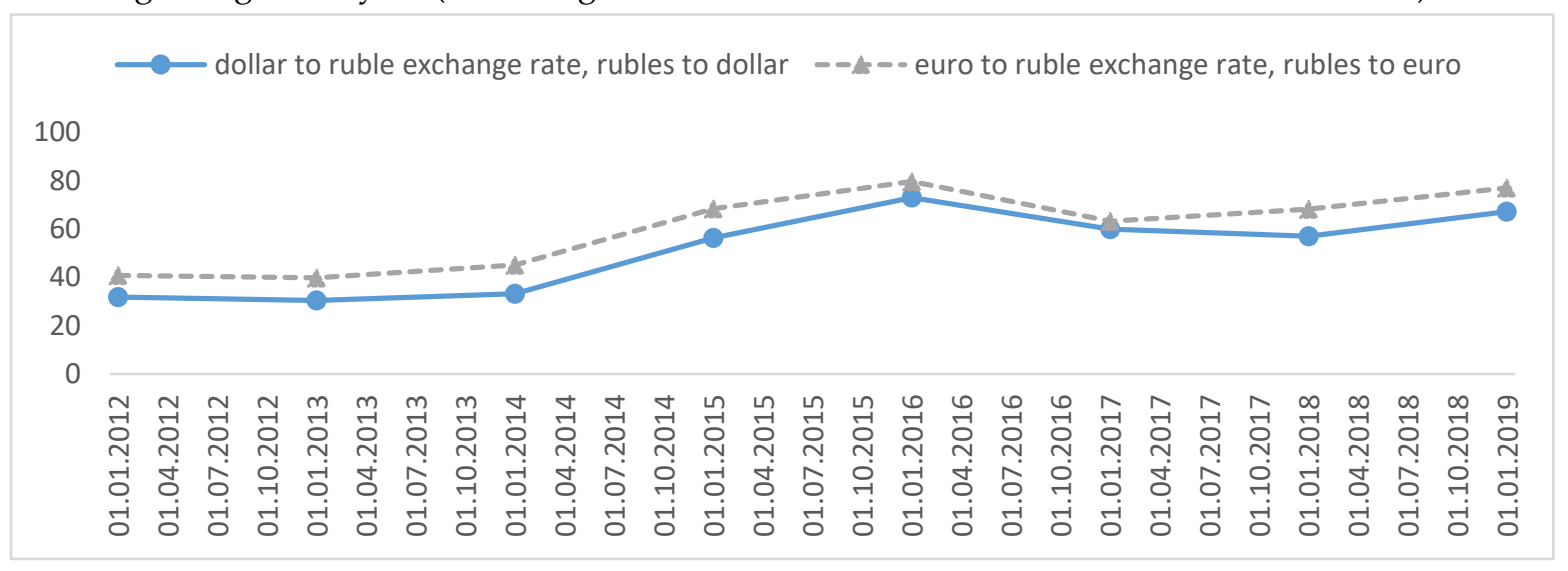

Figure 2. The exchange rate of major foreign currencies against the Russian ruble in 2012-2018 (according to data of the Central Bank of the Russian Federation).

The positive impact of devaluation affects export-oriented industries. The volume and dynamics of Russian goods export according to Rosstat are presented in Figure 3. The negative impact of 
devaluation results in a sharp cost increase of imported goods, equipment and technology (it compounds an outright ban on machinery and technology supply).

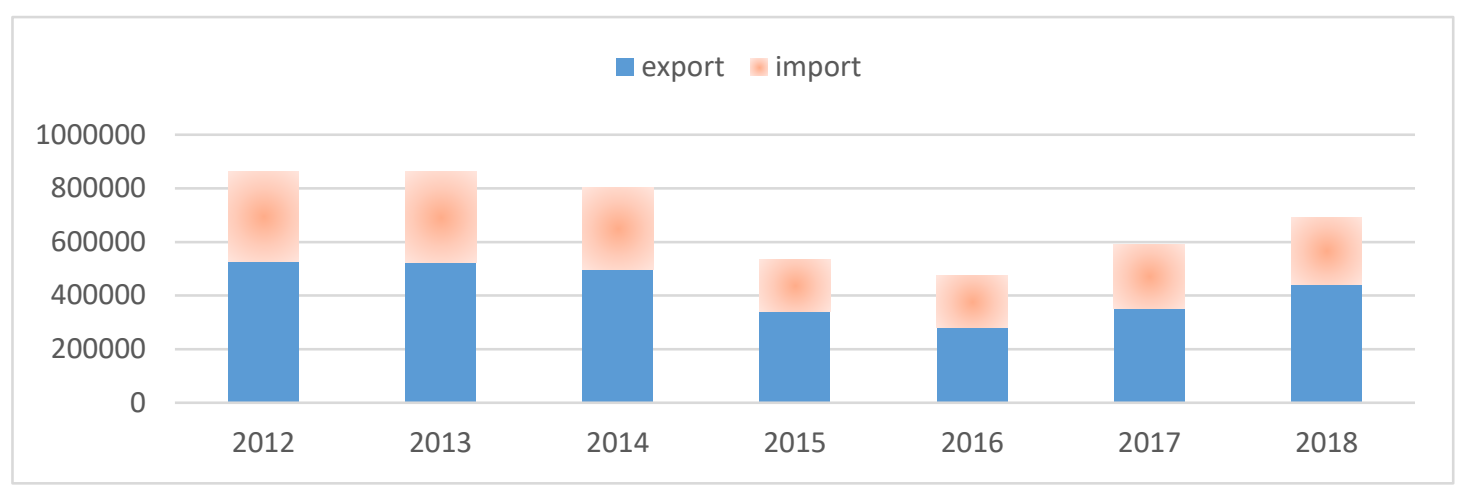

Figure 3. Dynamics of Russian foreign trade balance (based on balance of payments method) (according to the Federal Service for State Statistics data).

The data on Figure 3 indicates a decline in export-import operations volume as a result of international financial and economic sanctions. In 2014, Russia's foreign trade turnover decreased by $6.9 \%$ compared to 2013 . It amounted to $\$ 804.7$ billion including $\$ 496.7$ billion in export $(94.9 \%$ of 2013 ) and $\$ 308$ billion in import ( $90.2 \%$ of 2013 ). Trade balance remained positive amounting to $\$ 188.7$ billion ( $\$ 181.9$ billion in 2013). According to the Central Bank of the Russian Federation, in 2014 trade turnover between Russia and countries further afield amounted to $\$ 428,929 / \$ 271,978$ billion (export/import); trade turnover between Russia and CIS amounted to $\$ 68,834 / \$ 36,048$ billion (export/import).

By 2019, export volume has almost reached pre-sanctions performance, while import volume is still lower by almost a third. Despite fluctuations in foreign trade operations volume, the balance of payments of the Russian Federation remained positive - export volume has always exceeded import volume. One of the reasons for that was the devaluation of the Russian national currency which made Russian goods more competitive on the global market. Another reason is that the Russian economy as a whole is focused on commodity exports.

As shown above, international financial and economic sanctions impact the entire Russian economy. In addition, the list of sanctions clearly highlights the so-called "sectoral" sanctions aimed at destabilizing the situation in Russia's priority economic sectors. One can evaluate the way sanctions affected Russian industry by characterizing pre-sanctions industrial output in Russia and compare it with similar indicators during the sanctions.

According to Russian legislation, industrial production refers to "a combination of economic activities defined by the Russian Classification of Economic Activities and related to mining, manufacturing, electricity, gas and steam, air conditioning, water supply, drainage, waste collection and recycling, as well as pollution liquidation" (Law of the Russian Federation "About industrial policy in the Russian Federation»).

The analysis of industry in this study implies it to be defined as a set of extraction and manufacturing industries, as well as power, gas and water production and distribution. Being the core of material production, industrial production will be characterized by the following indicators:

- Industrial production in value terms;

- Industrial production index;

- Balanced financial result;

- Total cost per 1 ruble of product.

State of the industry data is based on the information provided by the Federal Service for State Statistics. Figure 4 shows industrial production dynamics in value terms in $2010-2013$. 


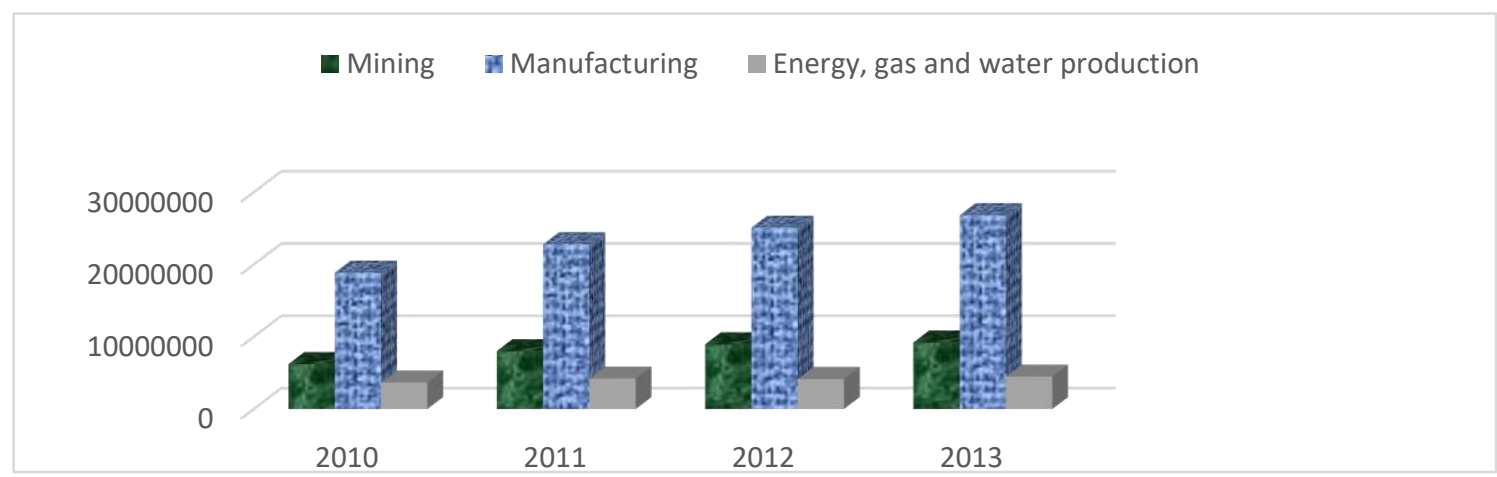

Figure 4. Russia's industrial production in 2010 - 2013, million rubles (according to the Federal Service for State Statistics data).

The data show that industrial production grew steadily in 2010-2013 but growth rates were uneven. In 2010-2012 mineral extraction volume growth exceeded inflation rates in value terms (i.e. there was a real increase in output), whereas in 2013 there was nominal growth as the output growth rate did not exceed the inflation rate in the same period. Manufacturing output grew more evenly and strongly. During the period under review there was a real increase in output (gross output growth rate exceeded the inflation rate growth in value terms in the same period).

The growth rate of production and distribution of electricity, gas and water was even more uneven. The output in value terms in 2013 to 2012 increased at about the inflation rate. i.e., in fact, the production volume has not changed in kind. In 2012 the growth rate in output in value terms was $98.6 \%$ compared to 2011 . Thus, there has been a decline in the production volume in this industry.

A more detailed change in industrial production in kind can be analyzed using the industrial production index. According to Federal Service for State Statistics methodology for statistical indicators compilation, the industrial production index is a relative indicator of change in production in comparable periods. For analytical purposes, a consolidated production index is used which characterizes cumulative changes in all types of products and reflects the change in the value generated in the production process as a result of changes in the volume of products alone. The industrial production index in this study is an aggregated production index for types of activity involving "Mining", "Manufacturing", " Electricity, gas and water generation and distribution" (Figure 5). The index is calculated by dividing the value of the current year to the corresponding value of the indicator for the previous year.

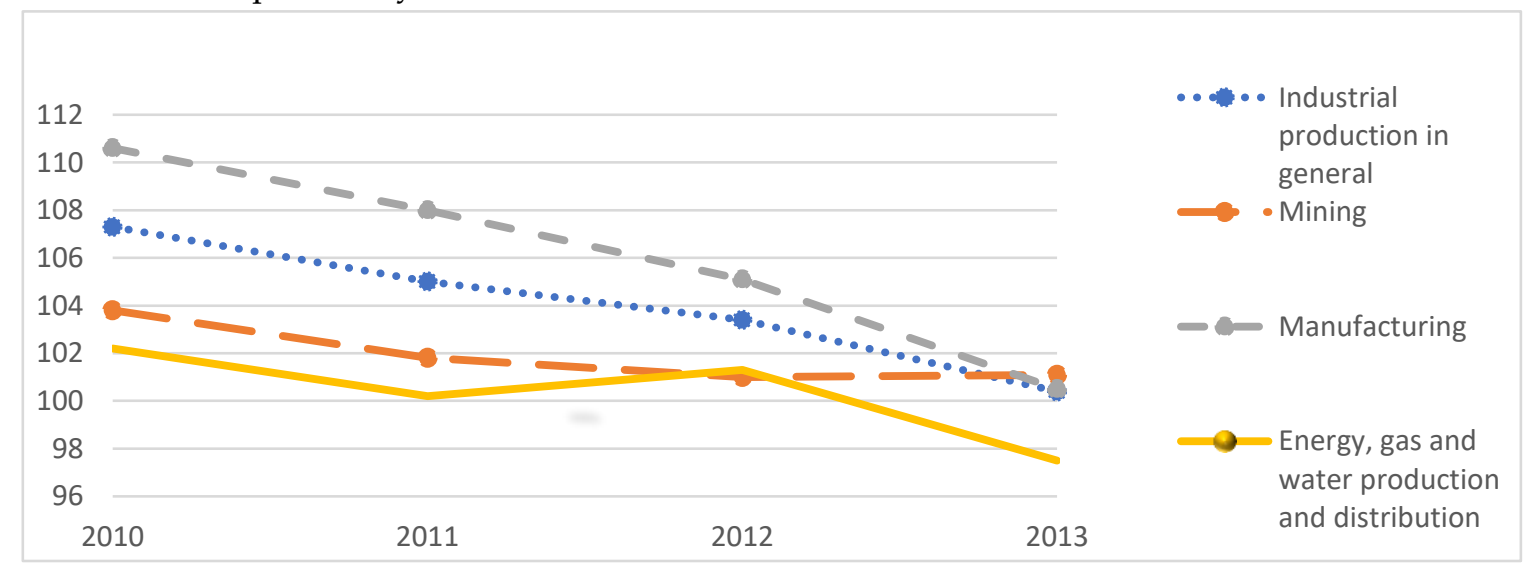

Figure 5. Change in the industrial production index in Russia in 2010-2013, \% (according to the Federal Service for State Statistics data).

The data shown in the chart illustrate a decrease in industrial production growth rate in Russia during the "pre-sanctions" period. At the time of imposing sanctions there has been a decline in output growth in all areas of industrial production. Furthermore, in some industries (electricity, gas and water 
production and distribution) there was a decrease in absolute production in kind. At the same time, it should be noted that industrial production growth rate as a whole remained positive throughout the "pre-sanctions" period.

According to Rosstat methodology, a balanced financial result is a final financial result based on accounting of all business transactions of organizations. It represents profit (loss) from the sale of goods, products, fixed assets, other assets of organizations and income from other transactions reduced by the amount of expenses on these operations.

Data on the balanced financial result of organizations are provided in actual prices, structure and methodology of respective years. Therefore, the analysis should be adjusted for the inflation rate in the same period. Data on the balanced financial result of industrial enterprises over the period analyzed are shown in Figure 6.

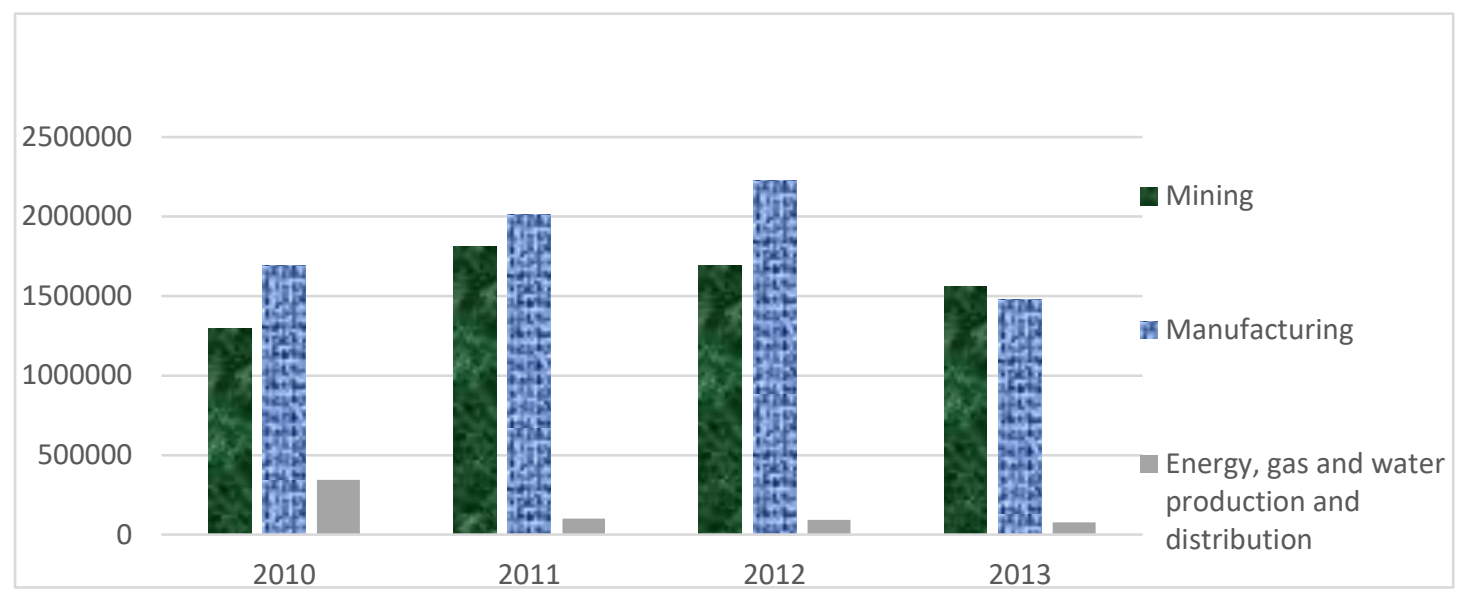

Figure 6. Balanced financial result (profit minus loss) of industrial enterprises in Russia in 2010-2013, million rubles (according to the Federal Service for State Statistics data).

The chart data show that balanced financial result dynamic in pre-sanctions period was very heterogeneous. In particular, in 2011 the increase in balanced financial result of extractive industries was $39.55 \%$ compared to 2010, and the increase in electricity, gas and water production and distribution was $-70.93 \%$. (i.e. there has been a nearly threefold decline in the balanced financial result in 2011 compared to 2010, but the balanced financial result remains positive, hence, in general the overall activity of industrial enterprises remains profitable).

As for the rest of the industry, 2011 was quite financially successful. In 2011, extractive and manufacturing industries showed a strong increase compared to 2010 (39.55\% and 19.0\% respectively in extractive and manufacturing industries). Then the situation changed, the dynamics of the indicator turned negative. In 2013 compared to 2012, the growth of the balanced financial result in all industry sectors was negative. For the industry as a whole production activities have become less profitable during the period under review.

The conditions in which industrial enterprises operate, as well as the results of their production activities, can be characterized by an indicator called the cost per 1 ruble of manufactured products. This indicator is important for comparing the "pre-sanctions" and "sanctions" period of organizations' activities. After sanctions were imposed on Russia and the national currency was devaluated, most enterprises working on imported raw materials experienced difficulties with its acquisition and, accordingly, with the increase in the production cost. As a result, their competitiveness in the market and the pressure on the inflation rate towards its increase have decreased. Data on the state and dynamics of industrial enterprises relative cost are shown in Figure 7. 


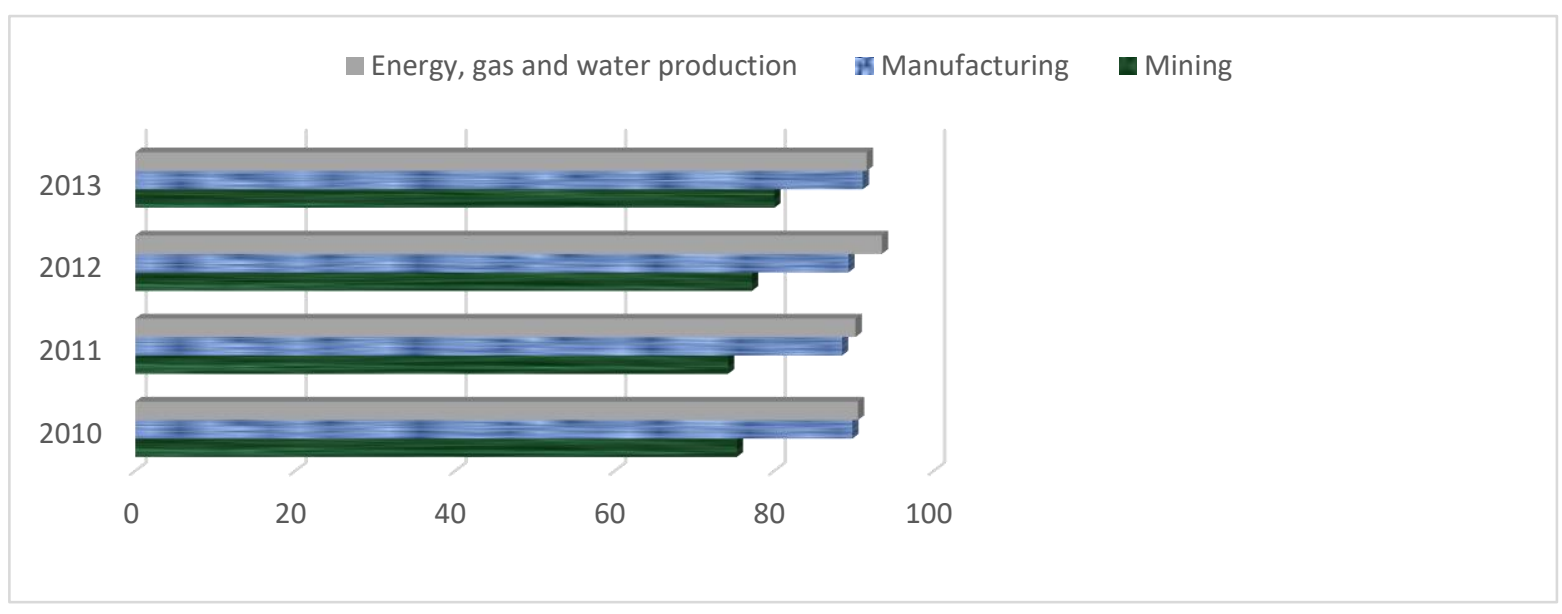

Figure 7. Cost per 1 ruble of manufactured products by industry sectors in 2010-2013, kopecks (according to the Federal Service for State Statistics data).

The analysis shows that, in general, there has been an increase in the unit cost in all industry sectors. This conclusion is consistent with the previous figure, which characterizes the change in the balanced financial result. In addition, it could be noted that the unit cost in industrial enterprises that produce and distribute electricity, gas and water is higher than in other industry sectors.

Thus, it could be concluded that Russia had had a number of accumulated problems by the time the international financial and economic sanctions were imposed. The main economic indicators of the industry show its deterioration - industrial production growth has decreased, unit costs have increased, the balanced financial result has decreased. At the same time, despite the slowdown, growth in Russian industries has nevertheless been observed, therefore the change of main indicators under the influence of sanctions should be analyzed.

The analysis of the current state of Russian industry will be conducted on the basis of separate reports of the Federal Service for State Statistics, in some cases the indicators will be calculated. It should be taken into account that methodological changes in economic activities data compilation which have entered into force in 2016 lead to some distortion of analysis results. The current state of the industrial sector of the economy will be characterized using the same indicators that were used to characterize the "pre-sanctions" state of the Russian industry. For the convenience of comparison, the analysis will include year 2013, prior to the imposition of sanctions.

The change in industrial output dynamics in value terms as a result of the sanctions is shown in Figure 8.

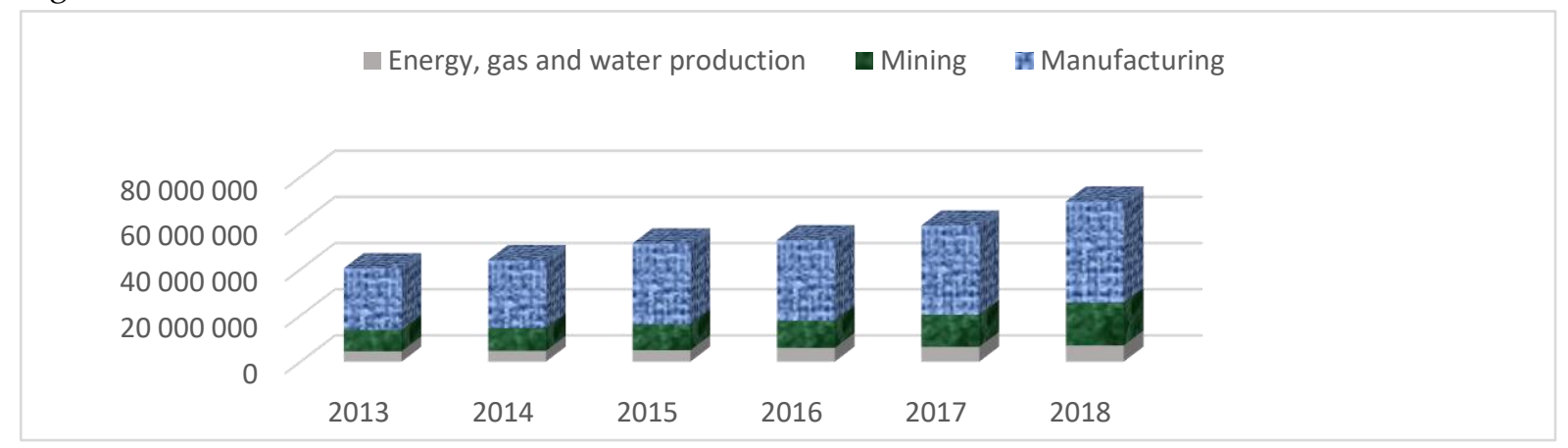

Figure 8. Industrial output dynamics in value terms in 2013-2018, million rubles (according to the Federal Service for State Statistics data).

Analysis of the data shows that, in general, industrial output in value terms for all types of economic activity grew in every period (except for manufacturing output in 2016, where it decreased by $0.35 \%$ compared to 2015). But this indicator is formed in value terms. Overall, the growth in industrial output in value terms was lower than the consumer price index in 2014 and 2016. In 2018, 
all types of economic activity demonstrated strong growth, which resulted in a growth rate of $17.6 \%$ compared to 2017. It seems that such a strong growth in difficult economic circumstances during the period under review was largely due to the devaluation of the national currency (increased price competitiveness of Russian products and the growth of foreign exchange earnings from exports also made an impact).

Industry analysis shows that the mining sector increased unevenly, from $104.3 \%$ in 2016 to $132.9 \%$ in 2018. The manufacturing sector showed stable growth, exceeding the consumer price index (except for the "drop" in 2016). A sharp increase in the production of electricity, gas and water in 2016 is related to the peculiarities of statistics compiling (the Russian Classification of Economic Activities has been modified). In general, this sector shows low growth rates usually not exceeding the consumer price index. But in 2017-2018, the situation changes and the growth volume in this sector exceeds the inflation rate, although lagging behind the industrial average.

The change in industrial production indices could be analyzed by industry as a whole and for certain types of economic activity (Figure 9).

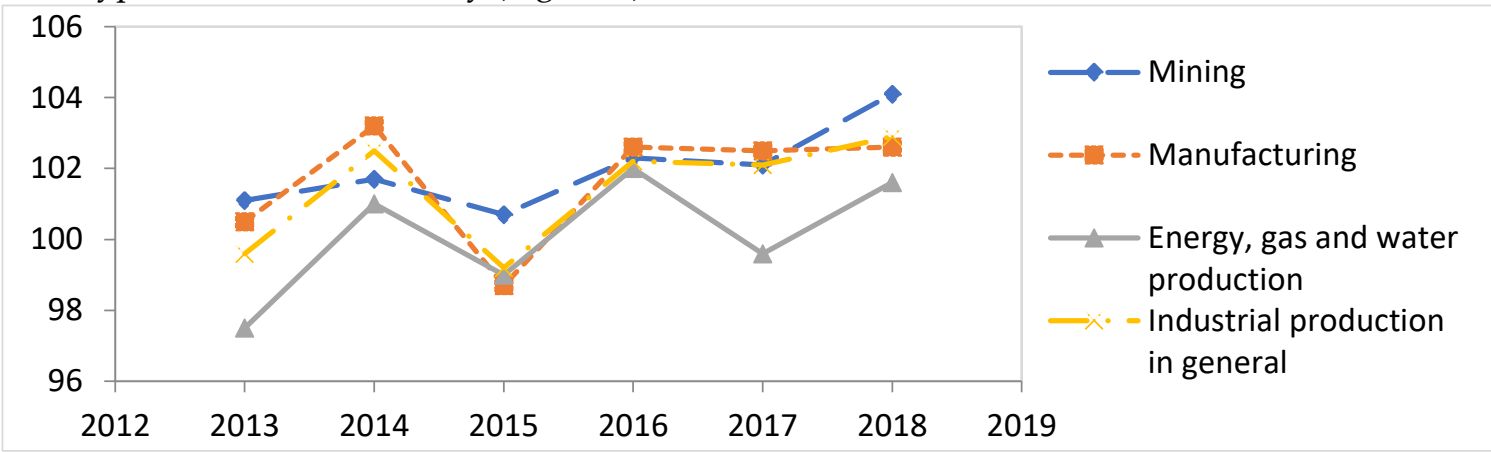

Figure 9. Industrial production indices dynamics in 2013-2018 (according to the Federal Service for State Statistics data).

It appears that the change in the industrial production index is a more objective indicator of the state of industry as it reflects a change in output volume. The Federal Service for State Statistics data show that the industrial production index as a whole remained positive after 2014 (the growth rate was generally at least $2 \%$ per year, except in 2015 when the index was $99.2 \%$ ). At the same time, for an objective assessment it should be taken into account that in 2014 the index was calculated by comparing the output reached in 2014 with the data from 2013 (when the output decreased compared to 2012). Therefore, the 2014 data are not that optimistic, although the industrial production output exceeded that in 2012.

Financial results of industrial enterprises are characterized by an indicator called balanced financial result. The data are presented in Figure 10.

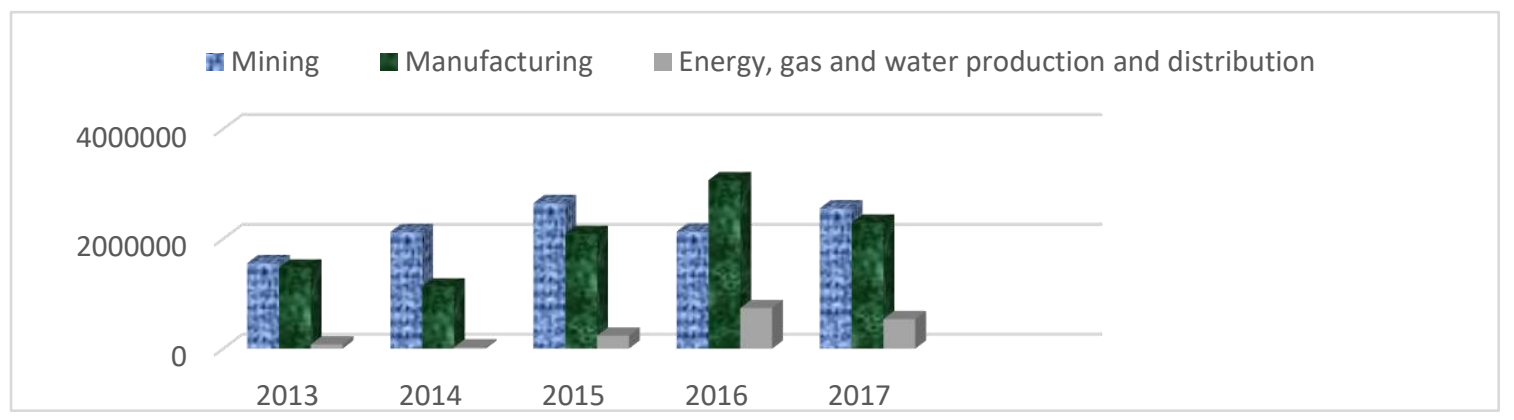

Figure 10. Balanced financial result of industrial enterprises (profit minus loss) in 2013-2017, million rubles (according to the Federal Service for State Statistics data).

The analysis shows that the balanced financial result of industrial enterprises remained positive even during difficult "sanctions" periods, i.e. the total profit by industry sectors exceeded the total loss received. But this indicator varied significantly from period to period. In addition, significant 
differences could be observed in the range of economic activities. It is important that since the imposition of sanctions the balanced financial result in mining has grown substantially (it can be explained by export revenues growth). In 2016, the indicator for fuel and energy mining companies was almost halved, while other mining enterprises showed a doubling of the balanced financial result.

The data for cost per 1 ruble of manufactured products are illustrated in Figure 11. Due to changes in compilation of indicators for electricity, gas, steam and water enterprises, it is impossible to determine it by calculation, as the results will be biased.

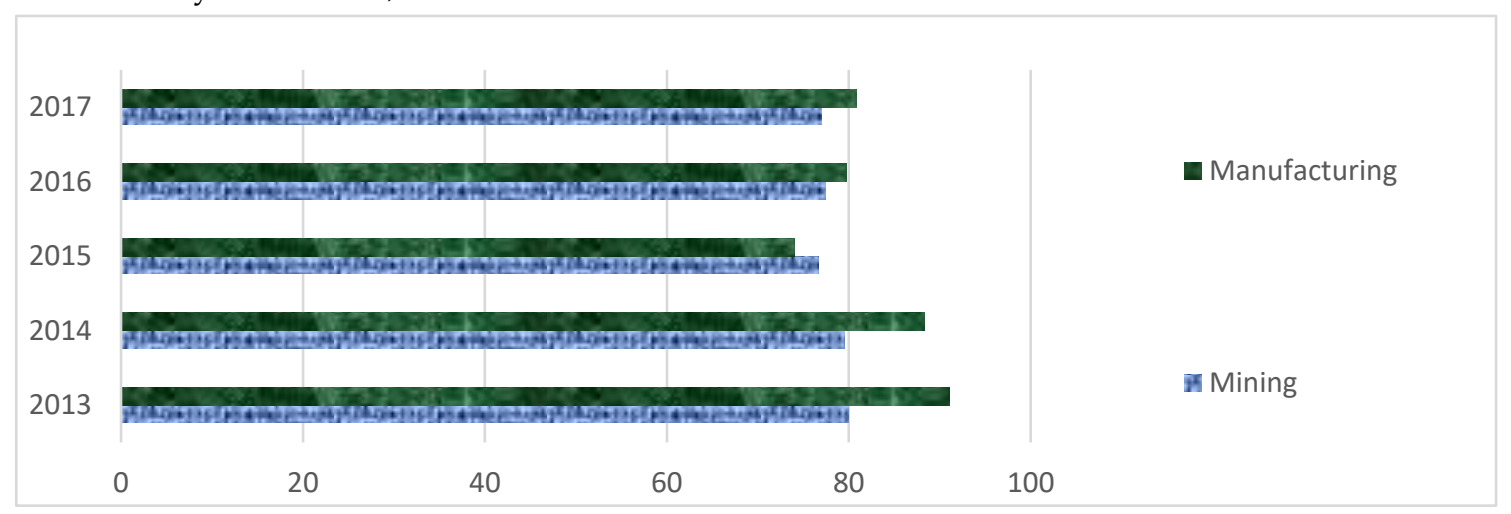

Figure 11. Cost per 1 ruble of manufactured products in 2013-2017, kopecks (Figures are calculated based on Federal Service for State Statistics data on production in kind and production costs).

Interestingly, in the period leading up to the imposition of sanctions, the cost per 1 ruble of manufactured products has been increasing in all types of economic activity. After 2014, the unit cost rate as a whole decreases for all types of economic activity. The result is quite unexpected given that imported raw materials have significantly increased in price. It can be assumed that the bulk of industrial enterprises is represented by companies working with domestic raw materials. Lower unit costs could also be led by lower labor costs.

\section{Discussion}

Thus, an analysis of the state of industrial production in Russia in the post-2014 period showed that (according to Federal Service for State Statistics) negative external pressure on the Russian industry did not lead to the collapse of the main indicators. Even under existing restrictions on access to credit resources, there is an increase in industrial production in physical terms (growth in value terms cannot be an objective criterion), balanced financial result remains positive in each reporting period.

Nevertheless, the negative consequences for Russian industry do exist. The author expects the onset of major negative consequences in the medium and long term. They may be led by a ban on Russia's import of machinery and technology in hydrocarbon production. This is mainly the case with offshore and Arctic drilling technologies. The deposits located there are classified as complex, and in order to master them Russia needs the technology developed by the European countries and the United States.

Currently, Russia looks forward to the East in search for affordable technologies. But the technologies that China is able to offer are inferior to the European ones. The author suggests that the lack of adequate technologies could soon lead to an increase in hydrocarbon production cost and a weakening of Russia's competitive position in the international market. Thus, the main objective for sanctions application could be achieved. At the same time, a number of Russian scientists believe that the imposition of sanctions on the fuel and energy sector has a dual effect. On the one hand, they have negative consequences. On the other hand, they create encouraging conditions for industry restructuring. (Ismagilova et al. 2017.)

There is often a positive assessment of the impact of sanctions imposed on Russian industry among Russian economists. Authors who share this position (e.g. a team led by R.M.Nureev, in a monograph "Economic Sanctions Against Russia: Expectation and Reality", 2019), suggest 
that sanctions will only lead to a slight decline in oil and gas production, while the countries initiating the sanctions will suffer from an increase in purchase prices of Russia's oil and gas resources. This position seems unfounded, given that (in the author's opinion) the purpose of imposing sanctions is to replace Russia's presence by the United States in the hydrocarbon market in Europe (primarily).

Another reason for a positive assessment of the impact of sanctions is the import substitution policy pursued by the Russian government (Novikov et al. 2019; Cherkesova et al. 2018). Some Russian researchers believe that "In general, we can talk about positive trends and an effective mechanism for the implementation of the import substitution strategy in Russia" (Novikov et al. 2019). According to the data (Novikov et al. 2019), the largest number of state import substitution programs is implemented in the aviation industry, by 2020 there should be 90 of them. In the area of mining it is expected to be 60 programs by 2020 .

Thus, it can be concluded that at the moment the economic sanctions imposed on Russia have caused a number of negative consequences against Russian industry. However, it should be admitted that Russian industry as a whole is coping with negative pressure. This is partly facilitated by the import substitution policy pursued by the Russian government. Despite this, the negative effects of the sanctions could have long-term consequences and manifest themselves in the medium and long term.

Acknowledgements: This article is written on the basis of researches conducted at the expense of budget funds in accordance with the government mandate for the Financial University.

\section{References}

Cherkesova E.Yu., Mironova D.D.,Slatvitskaya I.I., and Popova T.D. 2018. Sustainable import substitution in Russia: Institutional conditions and efficiency imperatives. European Research Studies Journal: 21(1), 287-295.

Hufbauer C. Gary. 2007. Economic Sanctions Reconsidered. Washington DC: Peterson Institute for International Economics.

Ismagilova Larisa, Gileva Tatiana, and Budnik Elena. 2017. Energy sanctions against Russia: Analysis and dualistic effect. Paper presented at the 30th International Business Information Management Association Conference, Madrid, Spain, November 5-9, pp. 4487-4489. Available online: https://ibima.org/acceptedpaper/energy-sanctions-against-russia-analysis-and-dualistic-effect (accessed on 31 January 2020)

Novikov S.V., Lastochkina V.V., and Solodova A.D. 2019. Import substitution in the industrial sector: Analysis and facts. Paper presented at the International scientific workshop: advanced technologies in material science, mechanical and automation engineering, Krasnoyarsk, Russian Federation, April 04-06, pp. 42-56. Available online: https://iopscience.iop.org/article/10.1088/1757-899X/537/4/042056 (accessed on 31 January 2020)

Nureev M. Rustem, and Petrakov P.K. 2016. Economic sanctions against Russia: expectations and reality. The world of new economy: 10(3), 14-31.

Nureev M. Rustem. 2017. Economic sanctions against Russia and Russian anti-sanctions: costs and benefits of confrontation. Herald of Dagestan State University. 32, 94-102. https://doi.org/10.21779/2500-1930-201732-3-94-102

Orekhovsky P.A. , 2018. Sanctions and counter-sanctions: left view. Terra Economicus: 3, 150-161. https://doi.org/10.23683/2073-6606-2018-16-3-150-161

Rosstat. 2019. Consumer price index for goods and services in the Russian Federation in 1991 - 2019. Available online: www.gks.ru/price (accessed on 10 September 2019).

Rosstat. 2019. Dynamics of the official rate of a given currency / Central Bank of the Russian Federation. Available online: URL:www.cbr.ru/currency_base/dynamics/ (accessed on 15 September 2019).

Rosstat. 2019. Foreign trade of the Russian Federation. Available online: URL:www.gks.ru/folder/11193 (accessed on 2 September 2019).

Rosstat. 2019. Industrial production. Available online: URL:www.gks.ru/folder/210/document/13225 (accessed on 22 September 2019).

Russian Federation. 2014. The Law of the Russian Federation Available online: http://www.consultant.ru/document/cons_doc_LAW_173119/(accessed on 15 August 2019). 